\title{
SOURCES OF KNOWLEDGE IN KNOWLEDGE MANAGEMENT IN CREATIVE SECTOR
}

\author{
ANETA SOKÓ $€,{ }^{1}$ IRENA FIGURSKA ${ }^{2}$ \\ ${ }^{1}$ University of Szczecin, Faculty of Management and Economics of Services, POLAND \\ e-mail: aneta.sokol@wzieu.pl \\ ${ }^{2}$ Pomeranian University, Faculty of Social Sciences, POLAND \\ e-mail: irenafigurska@vp.pl
}

RECEIVED

ACCEPTED

JEL

CLASSIFICATION

KEYWORDS

ABSTRACT
10 December 2018

28 December 2018

D81, D83

knowledge, economic knowledge, management, process, creative sector

Nowadays, the concept of competitiveness refers not only to the development of material resources and their impact on the economic expansion of individual economic units or larger structures such as regions. In the literature, it is assumed that the current success of the socio-economic development depends primarily on intangible factors such as knowledge and innovation. These resources are determined by the value of human capital, therefore much attention is devoted to its proper development. It is claimed that the quality of this capital determined by the level of employees' knowledge, influences the expansion and development of both successful enterprises and those in a difficult market situation. Therefore, the main focus of this article is to determine the sources of information and knowledge used in the process of managing knowledge in companies and to identify the level of the awareness of entrepreneurs on the benefits that properly used knowledge brings to the organizations. In order to achieve the assumed goal, focus studies were conducted among the employees of enterprises from the SMEs sector located in the West Pomeranian Voivodship.

\section{Introduction}

Nowadays, knowledge determines the value of the organization, and a management of the company is more and more often related to undertaking investments in the development of information and communication technologies, software, networks, databases, etc. All these elements stem from knowledge, which along with other intangible assets of the organization influences its competitive position on the market. Therefore, organizations 
building their market competitive position based on knowledge must take actions to assess existing intangible resources and identify both internal and external gaps in knowledge. Lack of activities in this area leads to a gradual loss of competitiveness by organizations. Therefore, knowledge is the superior causative factor of all decisionmaking processes and their cause and effect relationships in economies and organizations, especially those that base their activity on creativity. In order for knowledge to bring the expected benefits to the organization, it must be used wisely. However, the implementation of this process requires identification of sources of knowledge and ensuring access to them.

\section{Knowledge management in the oryanization - introductopy issues}

Referring to contemporary concepts of both entire economies' and individual entities' development based on the proper generation of knowledge, it should be emphasized that intellectual capital is of decisive importance in this process. A properly educated employee, possessing specific knowledge and skills of its practical use, becomes a valuable source in the process of design and implementation of new solutions, including in the area of management methods and techniques. In line with the current economic trend, the ability to use the achievements of science and practice so that the company gains the high position in the market competition, should be focused on the issue of knowledge management (see autohors: P. Drucker, P. Strassmann, P. Senge, Ch. Argyris, Ch. Bartlett, D. Leonard-Barton, E. Rogers, T. Alle, D. Engelbart, R. Acksyn, D. McCracken, T. Stewart, I. Nonaka, T. Hirotaka, I. Figurska,, A. Sokół, I. Figurska). Knowledge management is of interest to representatives of various scientific disciplines (e.g. philosophy, sociology, management, economics, information technology and others.), therefore the one definition of KM that would be widely accepted in scientific and business circles has not been elaborated as yet. Selected definitions of knowledge management are presented in Table 1.

Definitions of knowledge management point to some common goals of this process, which include: knowledge creation, storing, dissemination and use, identification of valuable and useless knowledge, reducing the risk of losing knowledge and finally - raising the organizational advantage.

Table 1. Definitions of knowledge management

\begin{tabular}{|c|c|}
\hline Author(s) & Knowledge management is... \\
\hline 1 & 2 \\
\hline M. Sarvary & a business process thanks to which companies create and put in practice their institutional or collective knowledge \\
\hline K.M. Wiig & $\begin{array}{l}\text { "[...] the systematic, explicit, and deliberate building, renewal, and application of knowledge to maximize an enterprise's knowledge- } \\
\text { related effectiveness and returns from its knowledge and intellectual capital assets" }\end{array}$ \\
\hline G. Probst & $\begin{array}{l}\text { the amount of all initiatives and tools, thanks to which such processes as localizing, acquiring, improving, sharing and spreading, } \\
\text { measuring and defining adequate knowledge sources within the company are supported }\end{array}$ \\
\hline M. Armstrong & "[...] about getting knowledge from those who have it to those who need it in order to improve organizational effectiveness" \\
\hline D.J. Skyrme & $\begin{array}{l}\text { "[...] the explicit and systematic management of vital knowledge and its associated processes of creating, gathering, organizing, } \\
\text { diffusion, use and exploitation" }\end{array}$ \\
\hline $\begin{array}{l}\text { P. Murray, } \\
\text { A. Myers }\end{array}$ & a "collection of processes that govern the creation, dissemination and utilization of knowledge to fulfil organizational capabilities" \\
\hline K. Dalkir & $\begin{array}{l}\text { "[...] the deliberate and systematic coordination of an organization's people, technology, processes, and organizational structure in } \\
\text { order to add value through reuse and innovation" }\end{array}$ \\
\hline T. Davenport & "[...] the process of capturing, distributing, and effectively using knowledge" \\
\hline O. Serrat & $\begin{array}{l}\text { "[...] explicit and systematic management of processes enabling vital individual and collective knowledge resources to be identified, } \\
\text { created, stored, shared, and used for benefit" }\end{array}$ \\
\hline
\end{tabular}


1

\begin{tabular}{ll}
\hline M. Levinson & "[...] the process through which organizations generate value from their intellectual and knowledge-based assets" \\
\hline $\begin{array}{ll}\text { J. Girard, } \\
\text { J.A. Girard }\end{array}$ & "[...] the management process of creating, sharing and using organizational information and knowledge" \\
\hline I. Figurska & $\begin{array}{l}\text { "[...] a set of systematic, organized, thoughtful and flexible actions aimed at knowledge resources (individual, collective and } \\
\text { organizational; explicit and tacit) of the organization, taken and performed with the intention of achieving the objectives of the } \\
\text { organization efficiently and effectively". These actions enable the organization to realize knowledge management processes as well } \\
\text { as shape the environment conducive to KM, using for this purpose appropriate methods and tools }\end{array}$
\end{tabular}

Source: Sarvary (1999); Wiig (2008); Probst, (2004); Armstrong (2006); Murray, Myers (1997); Dalikir (2005); Skyrme (2003); Davenport (1994); Serrat (2009); Skrzypek, Sokół (2009), p. 35; Levinson (2007); Girard, Girard (2015), Figurska (2012), p. 276.

Organizations present different approaches to knowledge as a resource, and knowledge management, which is why different KM strategies are distinguished in practice. These include (Paliszkiewicz, 2007, p. 357):

- codification and personalization strategies (see autohors: M.T. Hansen, T. Tierney),

- strategies of knowledge creation, transfer or protection (see autohors: J.M. Bloodgood, W.D. Salisbury),

- leveraging, expanding, appropriating and probing strategies (see autohors: G. Von Krogh, I. Nonaka, M. Aben),

- strategies for: comprehensive knowledge management, knowledge transfer and shaping of best practices, management of knowledge about clients, personal responsibility for knowledge, intellectual property management, innovation and knowledge creation.

Organizations that communicate by means of knowledge exchange benefit in the form of innovation. However, it is worth noting that knowledge generates value for business only when it is transferred in the organization. The reduction of risk, which consists in avoiding of existing knowledge losses, can be achieved through storage, dissemination or re-use of knowledge, which is undoubtedly another advantage of this process. In addition, knowledge management leads to increased productivity, improved cash flow, increased customer satisfaction with better products and services, improved employee satisfaction and improved financial results of the organization (Grudzewski, Hejduk, 2004, p.103).

However, in order to achieve the above-mentioned benefits, knowledge selection should be done. Nowadays, a rapid growth of information and the growing need to use the right knowledge are observed. This is possible thanks to knowledge management that enables the organization to function effectively in a knowledge-based economy.

Knowledge management should encourage employees to creatively develop knowledge resources in organizations by mutual consultation, brainstorming, scientific conferences, seminars programming and designing plans and projects, creating the conditions for sharing ideas, facilitating access to ideas, creating innovative workshops as well as transformations of hidden knowledge into explicit.

Analyzing the literature of the subject, it can be concluded that most enterprises implement knowledge management systems to reduce costs and optimize operations (Sokół, Figurska, 2017, p. 24). This is done mainly through two processes called structuring and making accessible. The first one consists in collecting and systematizing information. Structuring enables the company to organize information into groups of data, which subsequently can be easily processed and shared. The process of providing appropriate information to target groups is facilitated by information and communication technologies, such as database or Intranet. Unfortunately, the use of knowledge management systems to create development by introducing innovations is still uncommon practice in organizations. It is worth emphasizing that a modern approach to knowledge management systems enables a better 
understanding of the competitive position that facilitates and /or shortens the process of implementing new products on the market. The purpose of such a system is to generate new knowledge and make it available to appropriate units of the company. Understandably, meeting such modernity requires IT infrastructure and other processes such as absorption or scanning. Absorption means acquiring knowledge and improving operational processes, while scanning means identifying, collecting data and associating it in such a way as to identify and solve problems that arise in the organization.

\section{Typology of knowledge sources}

In the knowledge based economy it is more and more difficult to locate knowledge that is necessary to make decisions and actions in the organizations. The important for the organization knowledge sources can be divided into internal and external. Internal sources are within the organization and include, among others, knowledge possessed by employees, all kinds of organizational documents, organizational culture as well as information and communications tools. On the other hand, external sources of knowledge are outside the organization, in its widely understood external environment. They include, inter alia: clients, suppliers, market, business environment, research centres, institutions of higher education, conferences, seminars, exhibitions, publications, consulting firms, knowledge brokers, market research agencies, business competitors, politicians, media, the Internet, best practices, employees' informal contacts and other sources (Skrzypek, Sokół, 2009, p. 35; Figurska, 2012, p. 276; Figurska, 2014, p. 211; Sokół, Figurska, 2017, p. 24).

What makes the important knowledge sources accessible is their presentation (visualization). The most popular methods of knowledge sources visualization include address books, communication networks, metaphors and knowledge maps.

Both internal and external sources of knowledge are important for the functioning and development of the organization. Internal knowledge sources create the organization's knowledge base and determine its ability to acquire and receive knowledge from the external environment. External sources of knowledge, in turn, play a critical role in the process of searching for new ideas and knowledge required for the emergence of innovation (Doloreux, 2015, p. 104).

Research on knowledge management in organizations conducted by I. Figurska in 2012 and 2016 brought interesting information about the use of internal and external knowledge sources by employees. Considering the internal sources of knowledge, respondents most often used the knowledge of their closest co-workers, superiors, as well as internal instructions, manuals and regulations. On the other hand, the least frequently used internal knowledge sources include: service operating as a discussion group, containing the employees' experiences and skills, a database of reports on tasks and projects and internal communication platforms. Considering external knowledge sources, the Internet, cooperating organizations, customers, professional publications, software and legislation were the most commonly used by the respondents, while knowledge brokers, politicians, market research agencies, patents, exhibitions and consulting companies were the least popular among research participants. The results of the study lead to the conclusion that generally respondents use internal sources of knowledge more often than external knowledge sources. What is more, they use these sources which are close, well known to them and easily accessible, rarely reaching for other, less accessible sources.

Summing up above considerations it should be noted that "there are many potential sources of knowledge, both in the organization and outside it. It cannot be clearly determined which ones (internal or external) are more 
important to achieve a competitive advantage by the organizations. It seems that the best option is a wise, thoughtful combination of knowledge from various sources in order to create new knowledge and use it in an innovative way for the benefit of the organization and its employees" (Figurska, 2019, p. 35).

\section{Sources of knowledge in knowledge management in the creative sector - research results}

The article presents the scope of the issues of own research concerning knowledge sources. The research area of this article includes both theoretical (literature studies) and empirical (conducted focused group interviews) analysis of the issues discussed. The application of appropriate scientific methods and procedures has allowed to define the concept of knowledge and its sources as well as to identify its impact on knowledge management in organizations from the creative sector.

The following methods were used in the research: analysis, synthesis, induction and deduction. The conclusion for the conducted research has been the answer to the following research questions: Do knowledge sources and the way they are used affect the correctness of the development process of creative sectors? How to improve the process of acquiring and using knowledge sources in order to increase the efficiency of knowledge management in the creative sectors?

Consequently, the following hypothesis was put forward: Effective acquisition and use of knowledge from various sources in the process of knowledge management determines the development of creativity in organizations from the creative sector, and thus the number of generated innovations.

In qualitative research, focused group interviews (FGI) were conducted. In the framework of the discussion, phenomena related to the issue of knowledge sources and their impact on knowledge management processes in the development of the creative sector were analyzed.

Focused group interviews were conducted in November 2018 among people aged 23 to 35 years. The study group consisted of 10 people (including 4 women), and the participants of the discussion were employed in creative industries such as: advertising, media, industry, publishing.

At the beginning of the research, participants of the discussion were asked what they associate the creative sectors with? Therefore, they were asked to finish the sentence: creative sectors are... In response, the participants of the discussion stated that the creative sectors are those whose core activity is innovation and which are related to creativity.

Next, participants were asked to indicate industries belonging to the creative sector. They listed the following industries: IT, advertising, architecture, design, innovative industry.

In answer to the next question about the types of activities that are best developing in their place of residence and work, participants of the discussion said: programming and advertising.

Then the respondents were asked: Does knowledge (its possession, development and proper management) contribute to the creation of creative works and, consequently, to innovation? The answers were different, although there was a general agreement that in the case of creating innovations of a specialist nature, knowledge possessed by people creating such products or services is of fundamental importance. There would be no technological progress without knowledge.

According to some people, education may be of secondary importance, because having passion can lead to increased knowledge in a given field, which can lead to the creation of unusual creative works. On the other hand, 
all persons participating in the discussion confirm that education ensures that the knowledge of people working in creative sectors is used in the process of creating innovations.

Another aspect of the study was an attempt to assess the need for introducing knowledge management systems in contemporary organizations. Study participants were asked the following questions: How organizations perceive the impact of effective knowledge management on processes occurring in them? What are the main factors motivating the organization to implement knowledge management systems?

The answers to the first question were very diverse. As the reason for the knowledge management implementation in the organization, the respondents listed: the increase in the value of the company, the desire to improve the competitive position of the company, acquiring new customers, better management of the company and improving innovation. The respondents indicated that proper knowledge management also allows for increasing the flexibility of the entity, improving decision-making processes, generating time savings, effective use of human, material and financial capital, reducing decision-making uncertainty, reducing the risk of losing knowledge.

The obtained answers lead to the conclusion that the most important benefit determining the organization's willingness to implement effective knowledge management systems is achievement of a competitive advantage by the firm, which enables its development and consolidates its market position.

However, in response to the question about factors motivating organizations to knowledge management systems implementation, the respondents mentioned: development of employees' competencies determining effective development of the company and its expected growth, introduction of innovations, acceleration of operations, improvement of customer satisfaction and reduction of operating costs.

Another area of analysis were IT solutions, which in recent years have been introduced in organizations in which the study participants work. In response to this question, only two persons pointed to the implementation of knowledge management systems using IT solutions in their organizations.

Then the respondents were asked where they source knowledge. Most of them indicated that the Internet, media and traditional sources are those knowledge sources which are the most often used by them. In addition, the press, conferences, bulletins, reports and brochures were recognized as effective sources of knowledge.

However, when asked about the use of incentives to share knowledge in organizations in which they work, the majority of respondents answered that they are not motivated to knowledge sharing.

The last issue raised in the discussion were the upcoming plans for the future regarding the implementation of integrated knowledge management systems (KMS) in organizations in which respondents work. Almost all of the respondents admitted that the implementation of KMS would be beneficial for the development of their companies.

\section{Conclusions}

Knowledge management is not yet another theoretical idea as it is evidenced by the fact that KM has already been successfully implemented in numerous organizations operating in various branches. However, a concept of knowledge management is still not well known. The implementation of knowledge management systems and the realization of KM processes (such as knowledge localization, acquisition, development, sharing, use and preservation) in organizations belonging to the creative sector encounters numerous barriers both in their internal structures and relations with the environment. However, in the light of the results of the conducted study, it can be stated that the majority of respondents are aware of the importance of using knowledge and the need to structure it, which is undoubtedly a positive trend. It is worth noting, however, that knowledge management in organizations 
is still at the stage of implementing individual projects, and the activities aimed at the realization of KM processes are not sufficiently formalized.

\section{References}

Armstrong, M. (2006). A handbook of human resources management practice. London.

Dalkir, K. (2005). Knowledge management in theory and practice. USA: Elsevier Butterworth Heinemann.

Davenport, T.H. (1994). Saving IT's soul: human-centred information management. Harvard Business Review, 72 (2). Retrieved from: https://hbr.org/1994/03/saving-its-soul-human-centered-information-management.

Doloreux, D. (2015). Use of internal and external sources of knowledge and innovation in the Canadian wine industry. Canadian Journal of Administrative Sciences, 32 (2), 102-112.

Figurska, I. (2012). Zarządzanie wiedzą w organizacji. Słupsk: Wydawnictwo WHSZ.

Figurska, I. (2014). Sustainable entrepreneurship: localization, acquiring and use of knowledge sources in competitive organization. Entrepreneurship and Sustainability Issues, 1 (4), 211-222.

Figurska, I. (2019). The comprehensive approach to knowledge management in the organization. Warszawa: CeDeWu (in print).

Girard, J., Girard, J.A. (2015). Defining knowledge management: toward an applied compendium. Journal of Applied Knowledge Management, 3 (1), 1-20.

Grudzewski, W.M., Hejduk, I.K. (2004). Zarządzanie wiedzą w przedsiębiorstwach. Warszawa: Difin.

Levinson, M. (2007). Knowledge management definition and solutions. CIO. Retrieved from: http://www.cio.com/article/2439279/ enterprise-software/knowledge-management-definition-andsolutions.html.

Murray, P., Myers, A. (1997). The facts about knowledge. Information Strategy, 11.

Paliszkiewicz, J. (2007). Dostosowanie strategii zarządzania wiedzą do oferowanych produktów i kluczowej wiedzy w małych i średnich przedsiębiorstwach. In: K. Piech, E. Skrzypek, E. (eds.), Wiedza w gospodarce, społeczeństwie, przedsiębiorstwach: pomiary, charakterystyka, zarządzanie (p. 357). Kraków: Instytut Wiedzy i Innowacji.

Probst, P. (2004). Zarządzanie wiedzą w organizacji. E-mentor, 3 (5).

Sarvary, M. (1999). Knowledge management and competition in the consulting industry. California Management Review, 41 (2), Retrieved from: https://journals.sagepub.com/doi/abs/10.2307/41165988?journalCode=cmra.

Serrat, O. (2009). Glossary of knowledge management. Knowledge Solutions, April. Retrieved from: https://www.adb.org/sites/default/ files/publication/27594/glossary-knowledge-management.pdf.

Skyrme, D.J. (2003). Knowledge management: making sense of an oxymoron, http://www.skyrme.com/insights/22km.htm.

Skrzypek, E., Sokół, A. (eds.) (2009). Zarządzanie kapitałem ludzkim w gospodarce opartej na wiedzy. Kraków: Instytut Wiedzy i Innowacji.

Sokół, A., Figurska, I. (2017). Creativity as One of The Core Competencies of Studying Knowledge Workers. Enterpreneurship and Sustainability Isssues, 5 (1), p. 23-35.

Wiig, K. (2008). Knowledge Management for the Competent Enterprise. Business Intelligence, 8 (10). Cutter Consortium.

Cite this article aS: Sokół, A., Figurska, I. (2018). Sources of knowledge in knowledge management in creative sector. European Journal of Service Management, 4 (28/2), 421-427. DOI: 10.18276/ejsm.2018.28/2-50. 